Article

\title{
Evaluation of Intelligent Transport Systems Used in Urban Agglomerations and Intercity Roads by Professional Truck Drivers
}

\author{
Natalia Drop * and Daria Garlińska (D) \\ Faculty of Economics and Transport Engineering, Maritime University of Szczecin, H. Pobożnego 11, \\ 70-507 Szczecin, Poland; d.garlinska@am.szczecin.pl \\ * Correspondence: n.drop@am.szczecin.pl
}

check for updates

Citation: Drop, N.; Garlińska, D. Evaluation of Intelligent Transport Systems Used in Urban Agglomerations and Intercity Roads by Professional Truck Drivers. Sustainability 2021, 13, 2935. https://doi.org/10.3390/su13052935

Academic Editor: Tomio Miwa

Received: 10 February 2021

Accepted: 2 March 2021

Published: 8 March 2021

Publisher's Note: MDPI stays neutral with regard to jurisdictional claims in published maps and institutional affiliations.

Copyright: (c) 2021 by the authors. Licensee MDPI, Basel, Switzerland. This article is an open access article distributed under the terms and conditions of the Creative Commons Attribution (CC BY) license (https:/ / creativecommons.org/licenses/by/ $4.0 /)$.

\begin{abstract}
Using intelligent transport systems in cities is gaining popularity. The fundamental aim of their existence is to improve safety and traffic flow and prevent congestion in city centres. All people moving around the city, such as public transport passengers, as well as truck and emergency vehicle drivers and drivers of passenger vehicles, are users of intelligent transport systems. Research which was carried out for the article entirely concerns functioning and utility of intelligent transport systems from truck drivers' experience. The main aim of the research was to evaluate services and tools within intelligent transport systems in European cities which are visited by Polish truck drivers. Our research indicates that most drivers (almost 98\%) stated that they find intelligent transport systems useful and $92.5 \%$ of interviewed pointed that intelligent transport systems help with their everyday work duties. Of all the tools in the survey drivers agreed that variable content signs, accommodative traffic lights, and extra road illumination have most influence in road safety. Identifying the most useful and helpful tools of intelligent transport systems will allow to define their preferred development directions from truck drivers' point of view.
\end{abstract}

Keywords: intelligent transport systems; urban logistics; urban freight transport; management; sustainable transport

\section{Introduction}

Road transport is the dominating branch in cargo traffic of Poland and Europe in general. As presented in Figure 1, since 2007 performance of road freight transport, measured in vehicle-kilometres, grew, until the economic recession hit the whole transport market in 2009 [1]. Until the year 2008, volume of urban traffic constantly grew. This growth included both, individual passenger traffic and freight transport, causing many inconveniences for every group of transport users-a drop in the safety level, intensification of congestion and increased pollution-which is said to cause the premature death of 348,000 people annually across Europe [2]. Then, in 2009, the world was struck by an economic crisis which caused a decrease in the number of cargo shipments. Later, as the situation began to stabilise, the number of shipments began to grow again, but not as quickly as before and it never reached the level from 2008. It could have been caused by societies' growing awareness about the harming effects of fuel combustion, and also growing popularity of other branches of transport, such as rail and maritime transport, which are more effective and cheaper for long-distance shipments and greater amount of cargo.

However, despite the smaller number of shipments than at the beginning of 21st century, cities are facing the same problems of pollution and especially traffic congestion. It is said that delays for drivers in urban areas worldwide reach up to $27 \mathrm{~h}$ yearly and this time is rapidly getting longer [4]. Based on a study conducted by Inrix, in Europe in 2017 British drivers spent most time in congestions - up to $32 \mathrm{~h}$ yearly-Germany and Slovakia were in second place, with delays reaching $30 \mathrm{~h}$ a year, and Luxembourg came 
third with $28 \mathrm{~h}$ of delays annually [5] (accessed on 14 August 2020). More specific data for each country can be found on provider's website. Cargo traffic is not the only cause of this situation. As shown by the data from Eurostat (accessed on 14 August 2020), in 2018 there were 288,521,012 motor-engine powered passenger cars registered in European Union. Additionally, according to Eurostat (accessed on 14 August 2020), in 2018 the average number of passenger cars per 1000 inhabitants reached 472 (by averaging the data for all EU countries).

\section{Annual road freight transport vehicle movements measured in vehicle-kilometres}

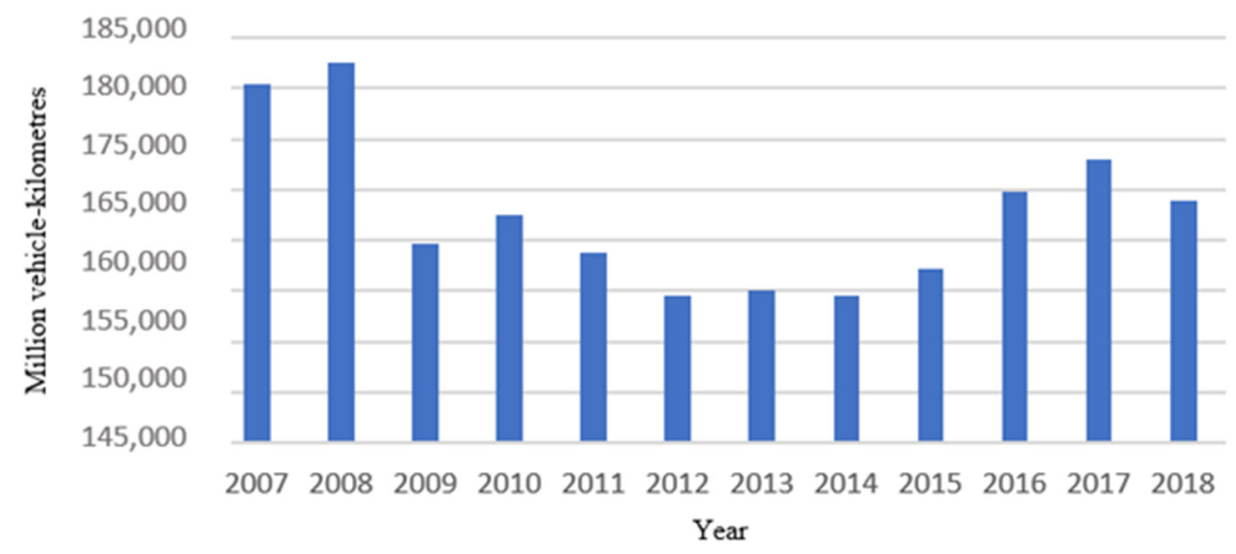

Figure 1. Annual road freight transport vehicle movements measured in vehicle-kilometres. Source: Author's own elaboration based on data from [3] (accessed on 18 March 2020).

A growth in movement by road, including shipments by road, caused imbalance between the intensity of traffic and the capacity of roads. The main difficulties that all road users face every day, such as congestion on city entry roads, greater amount of accidents and higher costs of damage removal, and a lack of parking places and greater degradation of natural environment [6]. This caused a necessity to come up with different ways leading to the facilitation of movement in city centres. These solutions are now called intelligent transport systems (ITS) and may be defined as a set of various tools that include IT, car electronics, wireless communication, telecommunication and wireless control. The genesis and structure of intelligent transport systems is presented by Figure 2.

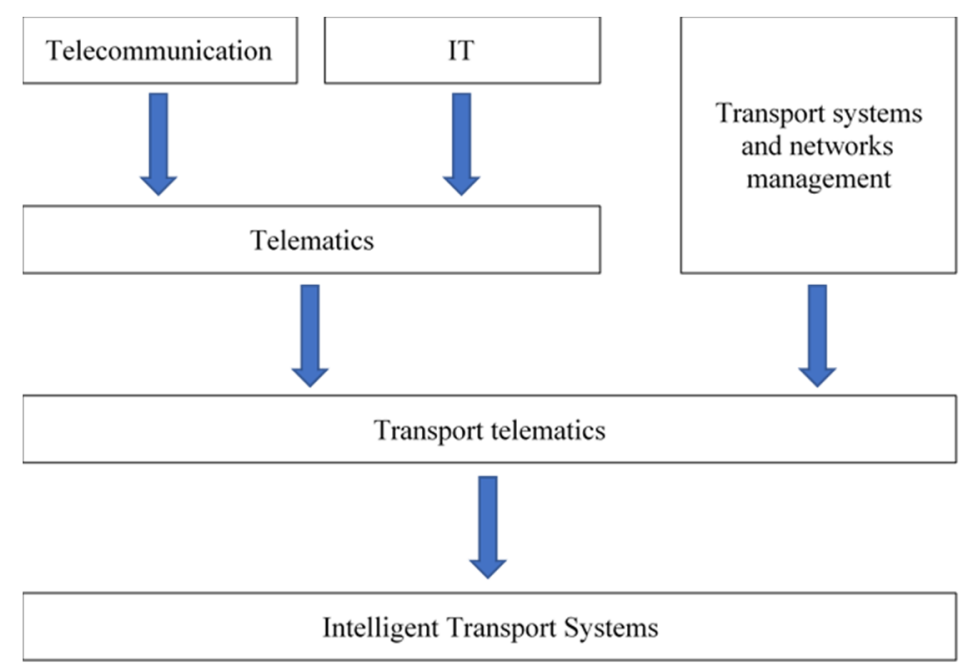

Figure 2. Origin of intelligent transport systems. Source: Author's own elaboration based on [7].

All this is used to manage traffic flow, public transport, cargo shipments and fleet, accidents, safety, emergency services, information and toll systems [8]. 
The aim of introducing intelligent transport systems is to [9]:

- increase efficiency of infrastructure and rolling stock,

- increase safety of road users,

- increase economic efficiency and competitiveness,

- lower negative impact on environment,

- develop multimodal solutions,

- improve cooperation between companies engaged in transport process, and

- improves integration and globalization of transport.

There are many various types of telematic systems that make intelligent transport systems and answer different needs of road users. All types and areas of application are presented in Table 1.

Table 1. Key services making up intelligent transport systems.

\section{Area of Application}

Traffic and journey management

Truck handling

\section{Performed Services}

Information supporting route planning Information about destination Personal data services

Navigation and supporting of route choice Optimizing traffic flow

Collecting data about control

Organizing movement of goods

Electronic truck briefing

Automatic road safety control Onboard monitoring of vehicle safety

Administrative support of trucks

Inspections of dangerous goods carriage

Managing truck fleet

Multimodal centres and warehouse services
Electronic toll collection systems

Public transport management

Road safety management
Electronic ticket distribution and transport agreements

Verification and confirmation of entrance fees

Managing agreements and shipping documents Detection of frauds
Organization and planning of public transport Monitoring of public transport

Information about road conditions Warning about danger

$$
\text { Driving support }
$$

Accident prevention

Video anti-collision systems

Collision prevention systems

Visibility improvement

Providing information about limitations of traffic caused by accident

Automatic control of level crossings

Safety of public transport

Safety services management

Road infrastructure management and maintenance

\section{Emergency}

Registration of accidents

Automatic safety services alarming Safety cars management

Infrastructure maintenance management

Key junctions' management

Special vehicles' management

Providing data about pollution 
Truck drivers delivering goods in cities constantly face difficulties in urban traffic. Considering dimensions and tonnage of truck, they have a limited route choice (limitations such as clearance under viaducts or maximum overall mass of vehicle) and time (just-intime deliveries). Therefore, from the driver's point of view, efficient management of urban traffic and the elimination of traffic congestion is vital.

\section{Literature Overview}

Cities are the main place of residence of large groups of people, of which most are consumers of goods and services. Therefore, road freight transport is an important element of functioning of urban areas, as it gives access to a wide range of goods and, thus, stimulates economic development [11]. However, in the second half of the 20th century city authorities began to consider problems arising from road transport of cargo. Freight transport in cities is seen as a source of pollution, noise, traffic congestion and have a negative impact on safety $[12,13]$ and, despite the civilizational need to move cargo by road, road transport in general is viewed in a negative way [14]. The volume of urban freight transport is constantly growing, causing demand for vehicle movement and service space, congestion, emission of GHGs (greenhouse gases) and noise, and accidents [15,16]. However, city authorities are constantly seeking ways of improving safety of traffic in cities, mostly by developing road infrastructure, resulting in less congestion and better accommodation of traffic flows [17]. Another possible solution can be applied in the field of management, and it is long-term planning, which includes not only current needs but also future trends, such as environmental protection, a shortage of fossil fuels, progressive urbanization and new environmental solutions, such as integration of reverse logistics with green logistics [18-20].

In the field of urban logistics, authors often raise issues of impact of truck transport on urban agglomerations and the environment. Authors of numerous scientific publications explore the issue and point out actions that are taken by city authorities to minimalize the negative impact of freight transport in cities [21-23]. Sustainable urban transport requires, from interested parties, developing new solutions and tools for its evaluation [24]. An example of such a tool is the collection and analysis of big data coming from trucks [25]. Each truck is equipped with a GPS system which records its route, speed and time and hereby allows to recognize drivers' habits. Based on this information, a real-time routing system has been designed and it was proven successful in reducing travel time in urban areas [26].

Transport that meets the assumptions of sustainable development, based on its three pillars, should include environmental, economic and social well-being. The environmental impact, in this case being emissions, can be measured using a formula that considers volume, distance and resource consumption of a single truck. Results obtained in this way can be used as guidelines for introducing tolls, dividing urban areas into zones with different principles (e.g., Limited Accessibility Zones) and, thus, reduce road freight transport in cities $[27,28]$. A great reduction of the carbon footprint and anthropogenic emissions in urban areas may also be obtained by bringing into service more vehicles powered with alternative fuels, especially electrically [29]. Another way of reaching sustainability is by promoting active transport - on foot or by bike - and a highly accessible, renewable energy-powered public transport [30]. Such solutions will need a high expenditure on modernization of the road network, but will make cities safer and more pleasant to live in.

A highly efficient transportation system has a huge impact on functioning of urban agglomerations, which is why solutions supporting management of urban areas are constantly sought for [31]. Large cities, due to a high number of transport users and vehicles, are facing a high intensity of traffic. Effective, in economic terms, management of urban traffic is mainly defined by a full use of existing resources, improvement of traffic flow, and prevention and minimalization of congestion and traffic congestion. The rising environmental and social awareness resulted in creation of a model that allows to measure progress of actions taken by city authorities to reduce the negative impact of freight transport on 
urban areas [32]. Supporting the effective management is possible through application of IT technologies [33]. One of innovative solutions to prevent negative results of heavy traffic in city centres is the use of widely developed Intelligent Transport Systems.

Intelligent Transport Systems are complex systems that involve all users of the widely understood urban infrastructure-drivers of all kinds of vehicles, passengers, pedestrians, road operators or city authorities. All these parties are linked together in and by a complex information and communication supporting infrastructure, whose task is to improve safety and efficiency of traffic flows [26,34,35]. ITS are also defined as high technologies in management, telecommunication, electronics (hardware) and IT (software) used to support surface transportation systems [36]. Intelligent transport systems are based on communication, IT and transport technologies, enabling to effectively manage urban infrastructure. Some authors point out that intelligent transport systems, especially in road transport in cities, translate into reduced distribution costs and increase in road capacity of urban transportation system (using existing road infrastructure) [37].

Assuming the positive effects resulting from use of intelligent transport systems is promising, but it often turns out that in reality the assumptions are not met. The creation of an effective transportation system, based on intelligent transport systems is also one of assumptions included in the White Paper strategy [38]. The plan to create a resource-efficient and homogenous transportation system includes also actions leading to safety improvement on roads and in urban agglomerations, such as harmonization and introduction of technologies and systems that support drivers, or intelligent speed limiters [38].

And as far as the impact of intelligent transport systems on ecology and environment $[39,40]$ is discussed in scientific works, the impact of systems on drivers' well-being, and especially in relation to professional drivers, is not mentioned too often. Papers on freight transport in cities rarely include drivers' opinions on implemented amenities. Drivers, as direct users of transport systems, are underestimated and their opinions are omitted. Many researchers e.g., [41] consider in their work the impact of various factors and parameters on driver's psychophysical condition at work. Authors [42] in their work discuss efficiency of only variable content signs from truck and taxi drivers' point of view and the impact of tools on the choice of route. This caused the decision of taking up the evaluation of telematic solutions used in urban agglomerations, from the point of view of professional truck drivers.

Technical support of truck drivers' work through tools specific of intelligent transport systems, which are dedicated to them, is highly important and brings benefits to both sides. It should be noted that systems enabling effective management of urban traffic are important due to growing demand on cargo shipments [37].

Authors [43] emphasize that to increase efficiency of intelligent transport systems mentioned above, other telematic tools and services must be used. Their mutual existence, integration and work gives better effects.

\section{Methodology}

After the literature analysis authors concluded that annual road freight transport grows, and cities must introduce solutions that would improve traffic flow in urban agglomerations. Authors also studied literature on intelligent transport systems-what they are, what tools and services do they include and who they benefit and found out there were no scientific studies that would describe intelligent transport systems from the point of view and dedicated specifically to truck drivers. On this basis authors noticed a research gap and decided to explore the topic. The aim of the research was to identify and prioritize tools and services of ITS for their utility for professional truck drivers. Then, basing on the adopted aim, the following research questions were asked:

1. Which tools of intelligent transport systems improve drivers' work the most?

2. What are the benefits of intelligent transport systems, according do truck drivers?

3. Should intelligent transport systems be further developed and why? 
Apart from literature touching issues of transport and intelligent transport systems, authors also explored literature concerning research methods. After collecting enough information, the decision was made that a survey would be the best tool to examine drivers' opinion on intelligent transport systems, because it allows to reach a relatively big receivers group in a relatively short time.

The second step was to choose tools and services of intelligent transport systems. Based on preliminary non-standardized interview, authors made a list of most common tools and services of intelligent transport systems. After analysing literature and results of the interview, fourteen tools and services, most important for urban traffic, from professional drivers' point of view, were chosen. Tools and services chosen for further analysis are:

- GPS and support of route choice,

- variable content signs (in the form of displays informing about conditions on road or warning about dangers, traffic congestion, detours, weather conditions),

- displays informing about occupation of parking lots,

- automatic identification systems for vehicles (such as recognition of license plates),

- electronic toll collection systems,

- safety cameras,

- accommodative traffic lights,

- displays showing vehicle's current speed,

- speed cameras,

- segmental speed measurement,

- road illumination (e.g., additional illumination of zebra crossings),

- dynamic monitoring of vehicle parameters,

- dynamic fleet and route management, and

- variable number of lanes, depending on traffic.

However, apart from the tools and services listed above, authors allowed the interviewees to name other solutions they might have come across, and that were not mentioned in the survey. In most cases, they inform about conditions on road or provide information about vehicle, but also allow the driver and law enforcement, such as the police department, to control safety of movement in cities. Some of them also speed up drivers' work by simplifying actions they have to perform during their worktime (e.g., electronic toll collection systems). The tools and services listed above were most frequently mentioned as the most helpful and most common during the preliminary survey in form of non-standardized interview.

The third, and last, stage of research was conducting a survey and analysis of its results. The survey was designed in a way that allowed collecting the most data without causing drivers too much trouble during its answering. This is the reason why it consisted mostly of closed questions, of which some were single, and some were multiple choice questions. A design like this also makes the results more measurable and reliable by eliminating differences in terminology or repeated answers. The tool used for survey was Google Forms. It allows to quickly collect answers, ask a wide variety of questions of different type, gather data and bring it up to date after every answer, facilitating their subsequent analysis (http:/ / forms.google.com, accessed on 7 April 2020). An electronic version of the survey has been widespread among drivers through groups dedicated to professional truck drivers in social media, such as Facebook and Instagram and later sent on by one driver to another. Furthermore, as a form of cooperation with a certain transport company, the survey was given to drivers working there. The research was a non-probabilistic study, based on random selection technique and the snowball sampling method. The research sample consisted of 146 professional truck drivers who had Internet access, since the survey was shared via social media and Instant Messengers. All drivers who had Internet access and/or social media account could participate in the survey. The snowball sampling allowed sharing the survey among drivers with no social media accounts, by sending the link from one driver to another. Main aim of the survey was to gather primary research material that was later used to evaluate tools and services of intelligent transport systems. The research was carried out from 17 March to 14 April 2020 continuously. 
The survey was anonymous and consisted of nine questions-three of them were semi-closed, five closed questions, all mandatory, and one open, which was optional to answer. All questions were intended to investigate drivers' knowledge on ITS and evaluate their utility based on interviewees personal experience.

\section{Research Results}

\subsection{Introduction}

The aim of the research was to identify and prioritize tools and services of intelligent transport systems used in cities, for their utility for truck drivers.

Creating intelligent transport systems and offered tools and services allows using them by all users of urban road infrastructure. This makes everyone: pedestrians and public transport passengers, drivers of both-public and commercial means of transport, users of intelligent transport systems. From users' point of view, the most important benefits of intelligent transport systems are:

- $\quad$ safety improvement (reduction of accidents by $40-80 \%$ ),

- reduction of travel time by $45-70 \%$, and

- improvement of comfort and conditions of movement for all users.

whereas, from the point of view of city authorities, benefits of Intelligent transport systems are:

- increase of street capacity by $20-25 \%$,

- reduction of fleet management cost,

- reduction of road maintenance cost, and

- increase of economic benefits for the whole region.

Moreover, the use of intelligent transport systems is meant to improve quality of natural environment-reduction of greenhouse gas emission by $30-35 \%$. It is visible that benefits not only concern urban traffic, but also economy and environment for all users.

Table 2 presents chosen tools and services dedicated to each group of users: pedestrians and passengers of public transport, drivers of truck and passenger vehicles. It shows that properly designed intelligent transport systems have tools/services that benefit all transport users.

Table 2. Tools and services dedicated to each group of traffic participants.

\begin{tabular}{|c|c|c|c|}
\hline User & Public Transport Passengers & Passenger Vehicle Drivers & Truck Drivers \\
\hline \multirow{5}{*}{ Tools } & Pre-trip information & Vision enhancement & $\begin{array}{l}\text { Commercial vehicle } \\
\text { administrative process }\end{array}$ \\
\hline & $\begin{array}{l}\text { On-trip public transport } \\
\text { information }\end{array}$ & Automated vehicle operation & $\begin{array}{l}\text { Automated roadside safety } \\
\text { inspection }\end{array}$ \\
\hline & $\begin{array}{c}\text { Personal information services } \\
\text { Route Guidance and } \\
\text { Navigation } \\
\text { Public travel safety }\end{array}$ & $\begin{array}{l}\text { Longitudinal collision } \\
\text { avoidance } \\
\text { Lateral collision avoidance } \\
\text { Safety readiness } \\
\text { Pre-crash restrain deployment }\end{array}$ & $\begin{array}{c}\text { Commercial vehicle on-board } \\
\text { safety monitoring }\end{array}$ \\
\hline & \multicolumn{3}{|c|}{ Emergency notification and personal security } \\
\hline & \multicolumn{3}{|c|}{$\begin{array}{c}\text { Safety enhancement for vulnerable road users } \\
\text { Incident management } \\
\text { Policing/enforcing traffic regulations }\end{array}$} \\
\hline
\end{tabular}




\subsection{Research Analysis}

The aim of the research was to identify and prioritize tools and services of intelligent transport systems used in cities, for their utility for truck drivers. The method used to carry out the research was a diagnostic survey and used tool was an online survey. The data presented below is based on answers coming from professional truck drivers. The basis for the categorization of answers was age and gender of the interviewees. The research group was formed of Polish, Ukrainian and Russian professional truck drivers, both men and women, aged from 18 to $66+$ transporting cargo on intra-European routes and the Near East (e.g., Azerbaijan, Kazakhstan).

As shown in Figure 3, the sample consisted of 91.1 percent of men and 8.9 percent of women, and the age structure of the sample is as it follows:

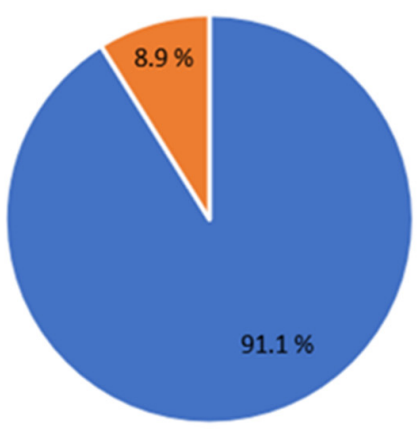

= Man = Woman

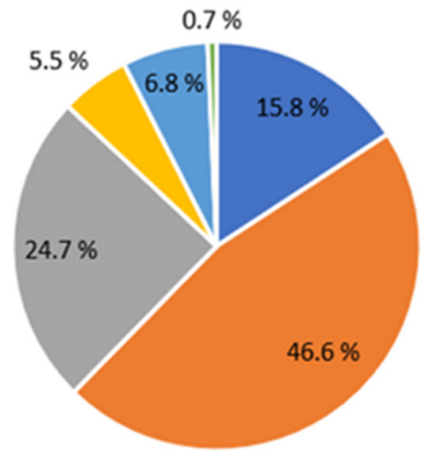

$=18-25=36-45=36-45=46-55=56-65 \equiv>65$

Figure 3. (left side) Gender structure of interviewees; (right side) age structure of interviewees. Source: Own elaboration.

The first question in the pivotal part of the survey concerned countries which drivers visit in their everyday work. Most accounted for European countries, however, few respondents listed countries outside Europe, such as Azerbaijan and Kazakhstan. The diagram below presents countries visited by surveyed drivers.

As shown in Figure 4, the country visited most frequently was Poland, up to $80.1 \%$ of interviewees gave such answer, Germany came in second place (with $75.3 \%$ of answers). Other often mentioned countries were France and Great Britain. As the question was semi-closed, drivers were allowed to point out other countries which were not listed by the authors. The answers often included Benelux countries, but also Slovakia, Hungary and Czech Republic. Respondents also mentioned Balkan countries-Bulgaria, Croatia or Bosnia and Herzegovina.

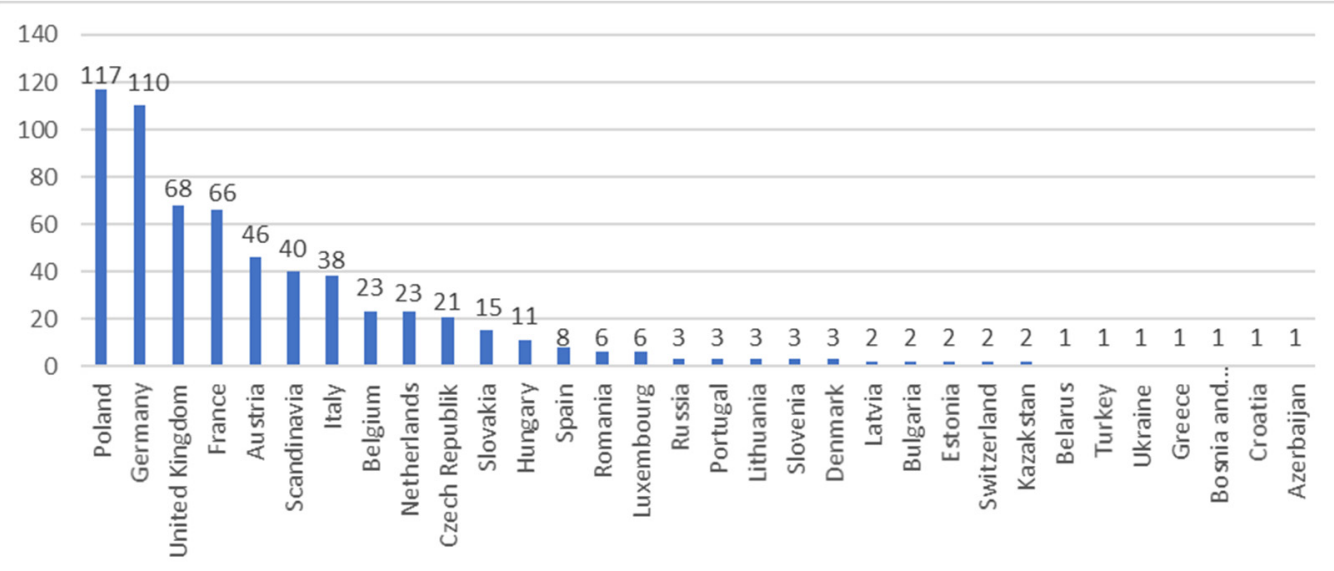

Figure 4. Countries visited by interviewed drivers in their everyday work. Source: Own elaboration. 
The key questions focused on services and tools of intelligent transport systems, which were known, found the most useful and safety-improving, from drivers' point of view. The question asking about the best-known tools and services of intelligent transport systems allowed drivers to choose more than one answer out of the 14 listed, but they also could give their own answer. Tools and services listed as answers were:

- GPS and support of route choice,

- variable content signs (in the form of displays informing about conditions on road or warning about dangers, traffic congestion, detours, weather conditions),

- displays informing about occupation of parking lots,

- automatic identification systems for vehicles (such as recognition of license plates),

- electronic toll collection systems,

- safety cameras,

- accommodative traffic lights,

- displays showing vehicle's current speed,

- speed cameras,

- segmental speed measurement,

- road illumination (e.g., additional illumination of zebra crossings),

- dynamic monitoring of vehicle parameters,

- dynamic fleet and route management, and

- variable number of lanes, depending on traffic.

As presented in Figure 5, tools most frequently chosen by interviewees were: tools supporting route choice, e.g., GPS, speed cameras and segmental speed measurement and variable content signs. Out of fourteen listed services and tools the least known was system of dynamic fleet and route management. Four respondents decided to give their own answers, out of which three mentioned electronic timers at traffic lights (counting time until change of light). Additioanlly, sensors for measuring tire pressure installed in road surface were mentioned. Figure below shows specific distribution of answers to the question about drivers' awareness of tools and services of intelligent transport systems.

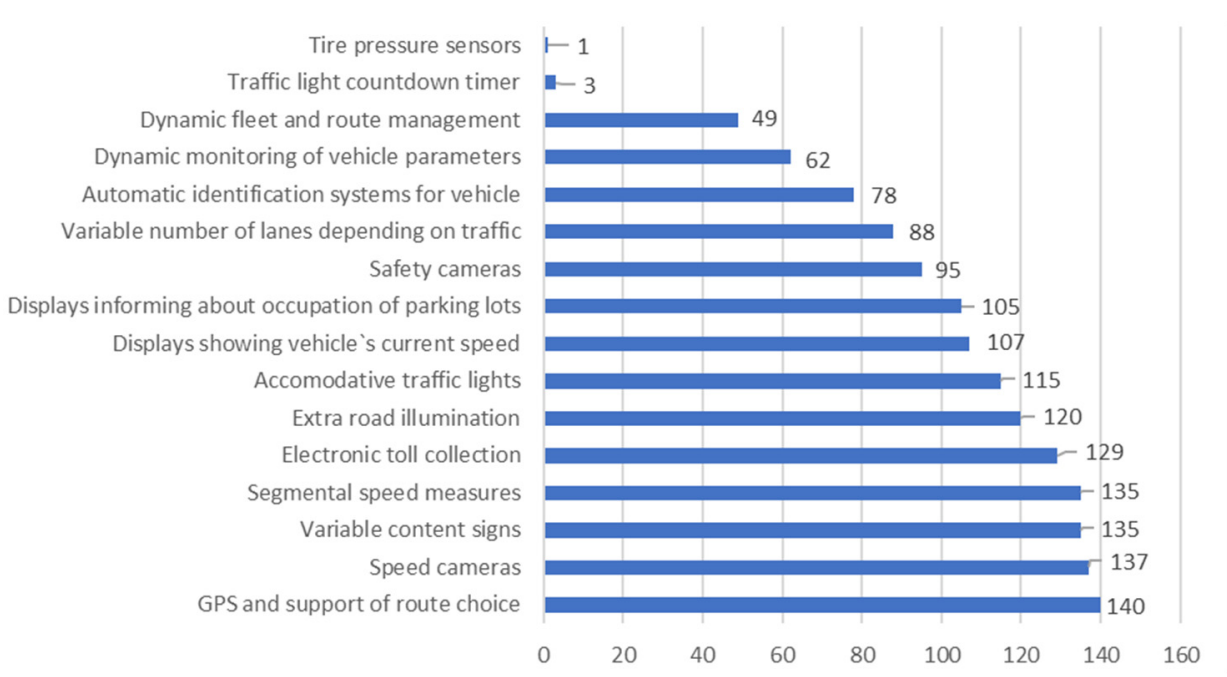

Figure 5. Tools and services of intelligent transport systems most frequently encountered by drivers. Source: Own elaboration.

Answers to the question concerning drivers' opinion on importance of listed tools and services of ITS were as follows: $78 \%$ of respondents pointed to two most important tools, which were tools supporting route choice and variable content signs informing about atmospheric conditions and accidents on the road. A total of $69 \%$ of interviewees marked extra illumination of roads as important. Moreover, more than half of people surveyed checked displays informing about occupation of parking lost (63\%), electronic toll systems $(52.1 \%)$, and optimizing traffic flows $(51.4 \%)$ as important. Least often, drivers pointed 
to automatic vehicle identification and systems of dynamic route and fleet management $(13 \%)$, and dynamic monitoring of vehicle parameters $(13.7 \%)$. The tools which were most frequently pointed out to, were independent of drivers' age, gender and route length or destination. Specific results are presented in Figure 6 below.

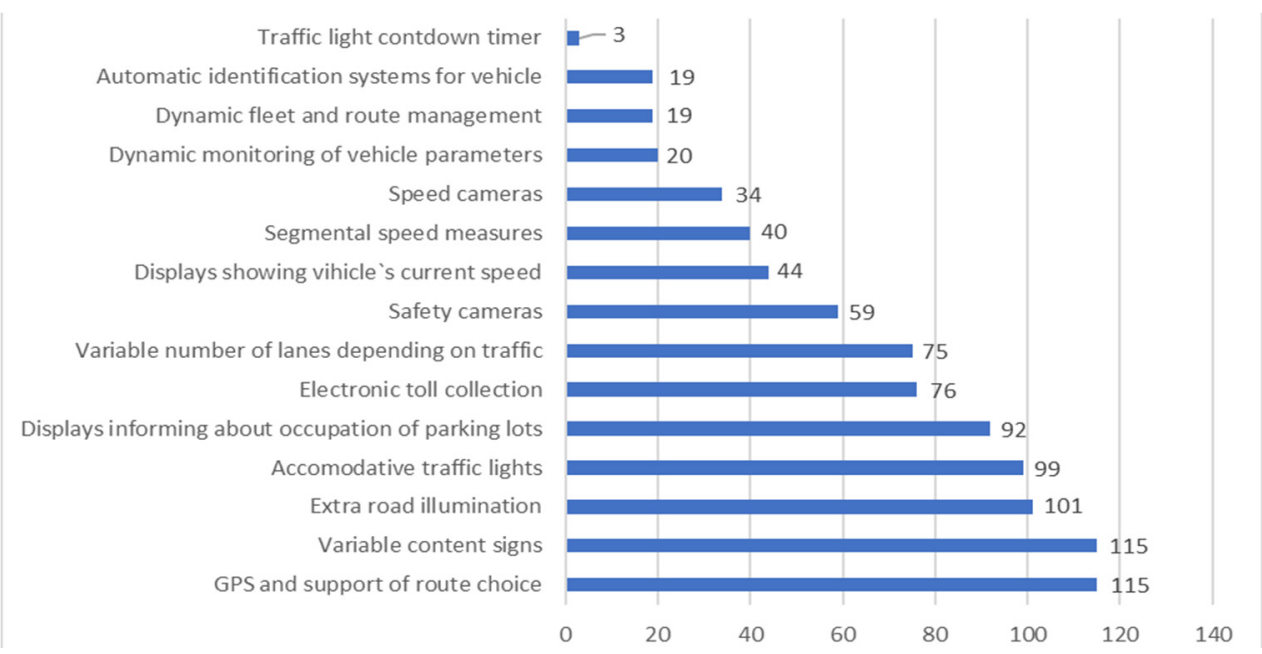

Figure 6. Importance of each tool/service of intelligent transport systems. Source: Own elaboration.

Analysis of survey results shown that there was no link between driver's age and importance of chosen tools. Most drivers, independent on their age, recognized GPS and support of route choice, variable content signs and extra road illumination as the most useful.

Respondents were also asked to determine the influence of each tool/service of intelligent transport systems on safety of movement on road. Answers were scaled from 0 (has no impact) to 4 (has huge impact) or I have no opinion. Drivers task was to give their opinion on every tool or service and its impact on safety. According to respondents most popular answers for each weight were:

- 0 (has no impact) - automatic identification systems for vehicles (40\%);

- 1 (has minimal impact) — displays showing vehicle's current speed and segmental speed measurement $(20 \%)$;

- 2 (has impact)—variable content signs (35\%);

- 3 (has notable impact)—variable number of lanes depending on traffic (16\%);

- 4 (has huge impact)—variable content signs (38\%);

I have no opinion-dynamic fleet and route management (21\%).

On the other hand, the least popular answers for each weight were:

- 0 (has no impact) - variable content signs and extra road illumination (3\%);

- 1 (has minimal impact)—extra road illumination (8\%);

- 2 (has impact)—dynamic fleet and route management (18\%);

- 3 (has notable impact) - automatic identification systems for vehicles and dynamic monitoring of vehicle parameters ( $8 \%)$; and

- 4 (has huge impact)—automatic identification systems for vehicles (7\%);

I have no opinion - variable content signs and displays informing about occupation of parking lots $(1 \%)$.

All detailed results for each tool/service of intelligent transport systems and each weight are shown in Table 3 below. 
Table 3. Importance of each tool/service of intelligent transport systems.

\begin{tabular}{|c|c|c|c|c|c|c|}
\hline & $\begin{array}{l}0 \text { (Has No } \\
\text { Impact) }\end{array}$ & $\begin{array}{l}1 \text { (Has Minimal } \\
\text { Impact) }\end{array}$ & $\begin{array}{l}2 \text { (Has } \\
\text { Impact) }\end{array}$ & $\begin{array}{c}3 \text { (Has Notable } \\
\text { Impact) }\end{array}$ & $\begin{array}{l}4 \text { (Has Huge } \\
\text { Impact) }\end{array}$ & $\begin{array}{c}\text { I Have No } \\
\text { Opinion }\end{array}$ \\
\hline $\begin{array}{l}\text { GPS and support of route } \\
\text { choice }\end{array}$ & $11 \%$ & $17 \%$ & $29 \%$ & $14 \%$ & $25 \%$ & $4 \%$ \\
\hline Variable content signs & $3 \%$ & $11 \%$ & $35 \%$ & $12 \%$ & $38 \%$ & $1 \%$ \\
\hline $\begin{array}{l}\text { Displays informing about } \\
\text { occupation of parking lots }\end{array}$ & $21 \%$ & $15 \%$ & $29 \%$ & $15 \%$ & $19 \%$ & $1 \%$ \\
\hline $\begin{array}{l}\text { Automatic identification } \\
\text { systems for vehicle }\end{array}$ & $40 \%$ & $16 \%$ & $20 \%$ & $8 \%$ & $7 \%$ & $9 \%$ \\
\hline Electronic toll collection & $29 \%$ & $15 \%$ & $23 \%$ & $10 \%$ & $17 \%$ & $6 \%$ \\
\hline Safety cameras & $11 \%$ & $19 \%$ & $30 \%$ & $13 \%$ & $21 \%$ & $6 \%$ \\
\hline Accommodative traffic lights & $5 \%$ & $13 \%$ & $29 \%$ & $11 \%$ & $34 \%$ & $8 \%$ \\
\hline $\begin{array}{l}\text { Displays showing vehicle's } \\
\text { current speed }\end{array}$ & $12 \%$ & $20 \%$ & $30 \%$ & $14 \%$ & $17 \%$ & $7 \%$ \\
\hline Segmental speed measurement & $11 \%$ & $20 \%$ & $31 \%$ & $13 \%$ & $20 \%$ & $5 \%$ \\
\hline Speed cameras & $15 \%$ & $18 \%$ & $32 \%$ & $13 \%$ & $16 \%$ & $6 \%$ \\
\hline Extra road illumination & $3 \%$ & $8 \%$ & $31 \%$ & $12 \%$ & $34 \%$ & $12 \%$ \\
\hline $\begin{array}{l}\text { Dynamic monitoring of } \\
\text { vehicle parameters }\end{array}$ & $24 \%$ & $16 \%$ & $26 \%$ & $8 \%$ & $9 \%$ & $17 \%$ \\
\hline $\begin{array}{l}\text { Variable number of lanes } \\
\text { depending on traffic }\end{array}$ & $6 \%$ & $13 \%$ & $30 \%$ & $16 \%$ & $23 \%$ & $12 \%$ \\
\hline $\begin{array}{c}\text { Dynamic fleet and route } \\
\text { management }\end{array}$ & $26 \%$ & $15 \%$ & $18 \%$ & $12 \%$ & $8 \%$ & $21 \%$ \\
\hline
\end{tabular}

Source: Own elaboration.

The following two questions were a yes/no questions and it concerned whether interviewed drivers consider ITS useful and helpful in their everyday work. As shown in Figure 7, out of total 146 answers 143 respondents found intelligent transport systems useful and it was $97.9 \%$ of all answers. Only $2.1 \%$ of all interviewees (three persons) thought intelligent transport systems are not useful.

Do you find Intelligent Transport Systems useful?

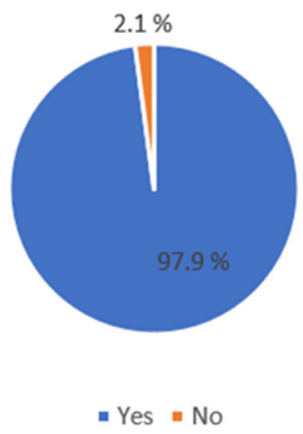

Do Intelligent Transport Systems help you in your everyday work?

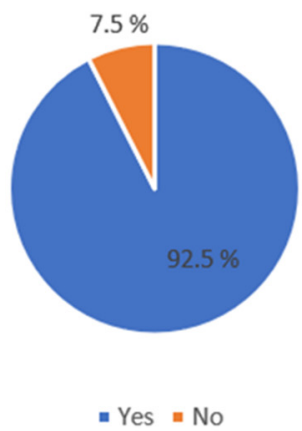

Figure 7. (Left) Usefulness of intelligent transport systems. (Right) Helpfulness of intelligent transport systems. Source: Own elaboration.

A large number of drivers (92.5\%) agreed that intelligent transport systems help them in their everyday work. Only $7.5 \%$ of interviewees answered the question negatively, claiming intelligent transport systems are not useful to them (Figure 7).

Next question asked if, in truck drivers' opinion, city authorities should invest in tools and services of intelligent transport systems. Figure 8 shows that, again, most respondents $(87 \%)$ claim that, in their opinion, city authorities should invest in tools and services of intelligent transport systems, only $1.4 \%$ said city authorities should not do it and $11.6 \%$ of interviewees did not have an opinion in this matter. 
Should city authorities invest in tools and services of Intelligent Transport Systems?

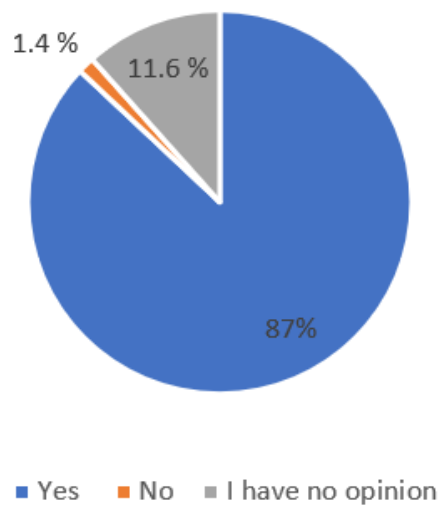

Figure 8. Necessity to invest in tools and services of intelligent transport systems. Source: Own elaboration.

One of questions asked in the research concerned areas on which intelligent transport systems have the greatest impact. This question allowed respondents to give multiple answers. At the same time, it enabled to answer the research question which concerned the benefits of intelligent transport systems for professional truck drivers. Most votes $(88.4 \%)$ were cast for improvement of traffic flow. $74.4 \%$ said, that systems improve safety of traffic, and $67.1 \%$ that on driver's work comfort. A minority of drivers noticed economic and ecological effects of implementation of intelligent transport systems- $32 \%$ marked both of these answers. Conclusion from these answers is that improvement of traffic flow is the most appreciated and noticed advantage of intelligent transport systems, from a professional driver's point of view. What is more, interviewees think that intelligent transport systems do not affect safety as much as they affect traffic flow. All environmental aspects are considered only by one third of respondents.

The last question was an open question and answering it was not mandatory. A total of 86 interviewees decided to answer it. Some answers were excluded, due to misinterpretation of the question or incomprehensibility of answer. The question concerned cities where drivers most frequently met some tools and services of intelligent transport systems. Most frequently, because up to 41 times, drivers mentioned Polish cities, primarily because up to $80 \%$ of respondents do their job in Poland. Cities which were mentioned most often were Szczecin, Warsaw and Poznan, as well as Wroclaw, Leszno and Plock. Except from Poland, drivers often listed cities in Germany (39 persons), Great Britain (30 persons), France (11 persons) and The Netherlands (11 persons). Among German cities drivers most frequently mentioned Berlin, Hamburg and Frankfurt am Main, among British—London and Manchester. Drivers also often mentioned Paris, Amsterdam and Rotterdam. Taking into consideration that drivers mainly mentioned biggest European cities, it may be concluded that authorities of large European cities invest resources in Intelligent Transport Systems. It has been noticed that drivers visiting both countries of Western and Eastern Europe (such as Russia, Romania or Kazakhstan) did not point to eastern cities as the ones where they encountered tools of ITS. Drivers agreeably say that they use intelligent transport systems and that they greatly affect traffic flow.

\section{Conclusions}

The aim of the research was to identify and prioritize tools and services of intelligent transport systems used in cities, for their utility for truck drivers. Authors focused on professional drivers' opinion on the utility of ITS in cities and intercity roads. This direction of research was chosen due to a small number of studies in this subject. Research was carried out on group of 146 professional truck drivers using the method of diagnostic 
survey. The exact tool used for the research was an online survey, consisting of nine questions of which eight were closed questions and one was an open question. The vast majority of drivers gave affirmative answers to questions concerning the validity of using intelligent transport systems and their utility in drivers' everyday work. Among the most helpful and commonly known tools and services of intelligent transport systems pointed out by drivers in the survey were: GPS and route support, variable content signs, segmental speed measurement and speed cameras. The research resulted in answering the research question concerning most helpful tools for professional truck drivers in their everyday work. Additionally, drivers pointed out that variable content signs, extra road illumination and accommodative traffic lights have the greatest impact on safety on the road. In the open question, willing drivers (the question wasn't mandatory) were asked about cities in which they encountered on tools and services of ITS. The answers showed clearly that, independent on route and destination, the biggest number of tools can be noticed in Western countries-mostly Poland, Germany, Great Britain and the Netherlands. Answers did not mention countries of Eastern and Southeastern Europe (e.g., Azerbaijan, Kazakhstan, Ukraine or the Balkans). This observation leads to a conclusion that Western European countries are far more advanced in use of ITS tools than countries of the east and southeast. In countries listed by drivers ITS are successfully used and lead to better accommodation of traffic flows and prevent congestion.

What is more, there is no dependence between drivers' gender, age and travel destination, and the choice of the most useful tools. All drivers, independent on division, chose the same useful tools.

Based on the research it can be concluded that intelligent transport systems are very helpful in professional drivers' work, they improve their work and positively influence safety of traffic in city centres and intercity roads. Tools and services of intelligent transport systems are more commonly used in large cities, which are positively received by drivers. Moreover, most respondents think that city authorities should continue on supporting development of said systems through investing in construction of new elements. It is an important conclusion for city authorities, which are considering implementation of ITS. Most drivers thought that the system should be developed, since it brings substantial benefits, not only for the interviewees but for all road users. Drivers also pointed out that the use of intelligent transport systems mostly improve traffic flow, and reduce the level of pollution.

The far-reaching effect of wide use of intelligent transport systems may be meeting the assumptions included in the white paper in the field of sustainable and resource-efficient transport system or meeting the assumptions of the sustainable road transport policy. In effect, negative effects of road transport, such as congestion, noise and environment pollution will face a drop.

Since professional truck drivers are a big group of road users, this research may be the starting point for further work on the subject of ITS. Further research should focus on several aspects:

- exploration in the field of ITS and their utility for professional drivers,

- $\quad$ raising awareness about ITS among all groups of road users, public authorities and logistic operators, and

- developing recommendations for entities responsible for implementation of specific tools city authorities and road operators.

Raising awareness among users about the utility of tools and services of ITS in urban agglomerations and on intercity roads could greatly affect performance of the whole transportation system and the ITS and improve safety on roads. Moreover, this research may be the basis for further research concerning the effect of ITS on safety, efficiency of traffic flows and directions of further development of the system.

This research faced two main limitations which were time and the way of dissemination. The survey was conducted from 17 March to 14 April 2020 continuously, which spans approximately a month and it was spread exclusively using social media, so all drivers willing to answer must have had te Internet access. In the future, similar studies should be 
carried out during a longer period of time and using a mix of online and direct tools for polling. Reaching a wider group of respondents will give more accurate results. Moreover, such research in the future could focus on the condition and popularity of ITS in specific countries or cities.

Author Contributions: All authors contributed equally to the compliation of this article and to the preparation of the final manuscript. All authors have read and agreed to the published version of the manuscript.

Funding: This research received no external funding.

Institutional Review Board Statement: Not applicable.

Informed Consent Statement: Informed consent was obtained from all subjects involved in the study.

Data Availability Statement: The data presented in this study are available in: http:/ / ec.eurostat.eu (accessed on 18 March 2020).

Conflicts of Interest: The authors declare no conflict of interest.

\section{References}

1. Koźlak, A. Struktura sektora transport drogowego w Polsce i ocena jego wyników ekonomicznych na tle państw Unii Europejskiej. Studia I Pr. Kol. Zarzadzania I Finans. 2018, 166, 59-75.

2. Jeż, M. Transport Lotniczy a Zrównoważony Rozwój; Biblioteka Naukowa Instytutu Lotnictwa: Warszawa, Poland, 2009.

3. Eurostat, European Comission. Available online: http:/ / ec.eurostat.eu (accessed on 18 March 2020).

4. Arnott, R.; Tilmann, R.; Schöb, R. Alleviating Urban Traffic Congestion, 1st ed.; MIT Press Books: Cambridge, MA, USA, 2005.

5. INRIX. Available online: http:/ /inrix.com (accessed on 14 August 2020).

6. Lewicki, W. Inteligentne systemy transportowe jako narzędzie inżynierii ruchu lotniczego. Autobusy Tech. Eksploat. Syst. Transp. 2012, 7-8, 106-111.

7. Barwiński, S.; Kotas, P. Inteligentne Systemy Transportowe w wybranych miastach Polski. Autobusy Tech. Eksploat. Syst. Transp. 2015, 10, 26-29.

8. Koźlak, A. Inteligentne systemy transportowe jako instrument poprawy efektywności transportu. Logistyka 2008. Available online: http:/ /akademor.webd.pl/download/kozlak_inteligentneST.pdf (accessed on 17 April 2020).

9. Wydro, K.B. Usługi i systemy telematyczne w transporcie. Telekomun. Tech. Inf. 2008, 3-4, 23-32.

10. Iwan, S. Wdrażanie Dobrych Praktyk w Obszarze Transportu Dostawczego w Miastach, 1st ed.; Wydawnictwo Naukowe Akademii Morskiej: Szczecin, Poland, 2013.

11. Cui, J.; Dodson, J.; Hall, P.V. Planning for Urban Freight Transport: An Overview. Transp. Rev. 2015, 35, 583-598. [CrossRef]

12. Allen, J.; Thorne, G.; Browne, M. Good Practice Guide on Urban Freight Transport; BESTUFS: Warszawa, Poland, 2007.

13. Taniguchi, E.; Thompson, R.G. Modeling City Logistics. Transp. Res. Rec. J. Transp. Res. Board 2002, 1790, 45-51. [CrossRef]

14. Quak, H.J. Sustainability of Urban Freight Transport: Retail Distribution and Local Regulations in Cities. Ph.D. Thesis, Erasmus Research Institute of Management, Erasmus University Rotterdam, Rotterdam, The Netherlands, 2008.

15. Kin, B.; Verlinde, S.; Macharis, C. Sustainable urban freight transport in megacities in emerging markets. Sustain. Cities Soc. 2017, 32, 31-41. [CrossRef]

16. He, Z.; Haasis, H.D. A Theoretical Research Framework of Future Sustainable Urban Freight Transport for Smart Cities. Sustainability 2020, 12, 1975. [CrossRef]

17. Grondys, K. The impact of freight transport operations on the level of pollution in cities. Transp. Res. Procedia 2018, 39, 84-91. [CrossRef]

18. Kiba-Janiak, M. Urban freight transport in city strategic planning. Res. Transp. Bus. Manag. 2017, 24, 4-16. [CrossRef]

19. Anand, N.; Quak, H.; van Duin, R.; Tavasszy, L. City logistics modeling efforts: Trends and gaps-A review. Procedia Soc. Behav. Sci. 2012, 39, 101-115. [CrossRef]

20. Morana, J. Sustainable Supply Chain Management in Urban Logistics. In Sustainable Urban Logistics: Concepts, Methods and Information Systems; Springer: Berlin, Germany, 2014; pp. 21-35.

21. Visser, J.; van Bisbergen, A.; Nemoto, T. Urban freight transport policy and planning. In Proceedings of the First International Symposium on City Logistics, Cairns, Australia, 12-14 July 1999.

22. Kotowska, I.; Kubowicz, D. The role of ports in reduction of road transport pollution in port cities. Transp. Res. Procedia 2019, 39, 212-220. [CrossRef]

23. Lindholm, M.; Behrends, S. Challenges in urban freight transport planning-A review in the Baltic Sea Region. J. Transp. Geogr. 2012, 22, 129-136. [CrossRef]

24. Behnke, M.; Kirschstein, T. The impact of path selection on GHG emissions in city Logistics. Transp. Res. E Logist. Transp. Rev. 2017, 106, 320-336. [CrossRef]

25. Kawamura, K.; Sriraj, P.S. Building freight-friendly environment. Transp. Res. Procedia 2016, 12, 119-131. [CrossRef] 
26. Taniguchi, E.; Thompson, R.G.; Yamada, T. Recent Advances in Modelling City Logistics. In City Logistics II; Institute of Systems Science Research: Kyoto, Japan, 2001.

27. Fläming, H.; Wolff, J. Impacts of planning and policy strategies on freight flows in urban areas. Transp. Res. Procedia 2016, 12, 584-597. [CrossRef]

28. Matusiewicz, M. Towards Sustainable Urban Logistics: Creating Sustainable Urban Freight Transport on the Example of a Limited Accessibility Zone in Gdansk. Sustainability 2019, 11, 3879. [CrossRef]

29. Wątróbski, J.; Małecki, K.; Kijewska, K.; Iwan, S.; Karczmarczyk, A.; Thompson, R.G. Multi-Criteria Analysis of Electric Vans for City Logistics. Sustainability 2017, 9, 1453. [CrossRef]

30. Woodcock, J.; Banister, D.; Edwards, P.; Prentice, A.M.; Roberts, I. Energy and transport. Lancet 2007, 370, 1078-1088. [CrossRef]

31. Kijewska, K. Analiza wybranych elementów Inteligentnych Systemów Transportowych w Szczecinie. Autobusy Tech. Eksploat. Syst. Transp. 2018, 6, 857-860.

32. Betanzo-Quezada, E.; Romero, J.A. An urban freight transport index. Procedia Soc. Behav. Sci. 2010, 2, 6312-6322. [CrossRef]

33. Lejda, K.; Siedlecka, S. Inteligentne Systemy sterowania ruchem w miastach. Autobusy Tech. Eksploat. Syst. Transp. 2016, 12, 680-683.

34. Williams, B. Intelligent Transport Systems Standards; Artech House: Norwood, MA, USA, 2008.

35. Perallos, A.; Hernandez-Jayo, U.; Onieva, E.; Garcia-Zuazola, I. Intelligent Transport Systems; Wiley \& Sons: Chichester, UK, 2016.

36. Sumiła, M. Pozyskiwanie informacji w systemach ITS, Prace Naukowe Politechniki Warszawskiej. Transport 2013, $100,202$.

37. Iwan, S.; Małecki, K. Zastosowanie rozwiązań telematycznych jako czynnik warunkujący efektywne zarządzanie miejskim transportem towarowym. Logistyka 2014, 3, 4128-4136.

38. European Environment Agency. Roadmap to a Single European Transport Area-Towards a Competitive and Resource-Efficient Transport System, COM 144 Final of 28 March 2011. Available online: https:/ / eur-lex.europa.eu/LexUriServ/LexUriServ.do? uri=COM:2011:0144:FIN:en:PDF (accessed on 26 April 2020).

39. Małecki, K.; Iwan, S.; Kijewska, K. Influence of Intelligent Transportation Systems on Reduction of the Environmental Negative Impact of Urban Freight Transport Based on Szczecin Example. Procedia Soc. Behav. Sci. 2014, 151, 215-221. [CrossRef]

40. Akgun, E.Z.; Monios, J.; Rye, T.; Fonzone, A. Influences on urban freight transport policy choice by local authorities. Transp. Policy 2019, 75, 8-98. [CrossRef]

41. Galkin, A.; Davidich, N.; Melenchuk, T.; Kush, Y.; Davidych, Y.; Lobashov, O. Moddeling truck's transportation speed on the route considering driver's state. Transp. Res. Procedia 2018. [CrossRef]

42. Poulopoulou, M.; Spyropoulou, I. Active traffic management in urban areas: Is it effective for professional drivers? The case of variable message signs. Transp. Res. Part A Policy Pract. 2019, 130, 412-423. [CrossRef]

43. Taniguchi, E.; Thompson, R.G.; Yamada, T. New opportunities and challenges for city logistics. Transp. Res. Procedia 2016, 12, 5-13. [CrossRef] 